\title{
ZNF496 wt Allele
}

National Cancer Institute

\section{Source}

National Cancer Institute. ZNF496 wt Allele. NCI Thesaurus. Code C89029.

Human ZNF496 wild-type allele is located in the vicinity of 1q44 and is approximately 31 $\mathrm{kb}$ in length. This allele, which encodes zinc finger protein 496, plays a role in the modulation of transcription. 